\title{
Study of the Indoor Air Quality in two Residential Houses according to their Ages
}

\author{
Sabah A. Abdul-Wahab
}

\begin{abstract}
The objective of this work was to explore the indoor air quality in two residential houses in Oman as per their ages, and to identify whether the quality of air in these two houses is acceptable for the residents or not. With a specific end goal to accomplish these objectives, the values of air quality parameters were taken at different areas of these two residential houses. The measured values of these parameters were then compared with the allowable values that are defined in international standards/guidelines. The results of the study demonstrated apparent elevated levels of $\mathrm{CO}_{2}$, TVOCs and temperature in the indoor environment of these houses which can affect the health of the residents.
\end{abstract}

Keywords-Indoor air quality, Air quality parameters, Age of residential houses, Oman.

\section{INTRODUCTION}

It is very important to verify that quality of air in the buildings is of a suitable standard to guarantee the sufficient assurance of the protection of occupants' well-being, productivity and health. The indoor air quality is impacted primarily by the accumulation of contaminants inside a building from different indoor and outdoor sources. Some sources of indoor air pollution are solvents used as a part of cleaning, building materials, paint, radon, allergens, smoking, plastics, carpets, and biomass burning for fuel or cooking [1].

Keeping in mind the end goal to keep up the health of the residents of the houses, the levels of physical, biological and chemical pollutants in the indoor environment ought to be kept under allowable standards. The elevated levels of indoor air contaminants have been connected with a wide cluster of health outcomes extending from clinically diagnosed illnesses to combination of ailments with temporal connection to a specific building, which are named as Sick Building Syndrome [2].

The current study was done recalling the importance to keep up appropriate and stable indoor environments for residential houses. Residential houses need such quality of indoor air which is acceptable for the protection of the health. In this manner, the point of this work was to identify whether the quality of air in the residential houses is satisfactory for the residents or not.

Keeping in mind the end goal to achieve this, the air quality parameters were measured for a time of no less than 24 hours at different areas of two residential houses, located in different areas of Muscat, the capital city of Oman.

Sultan Qaboos University, Sultanate of Oman, Department of Mechanical and Industrial Engineering
The indoor environmental parameters measured included, air speed, temperature, relative humidity, particulates, carbon dioxide, carbon monoxide, Sulfur dioxide, nitric oxide, hydrogen sulfide, nitrogen dioxide, ozone and total volatile organic compounds. The measurements were also compared with the available international standards/guidelines in order to assess the quality of air inside these buildings.

\section{II.DESCRIPTION OF SAMPLING SITES}

\section{A. House I: Residential Flat}

It is a newly built (2011) residential flat with area of $130 \mathrm{~m}^{2}$ and $3 \mathrm{~m}$ ceiling height. This flat is situated in a very populated area of Muscat having some industrial setups and a lot of construction work is also underway around it. It has a kitchen, two bed rooms, and a guest room. The location of this flat is little far from the main road.

\section{B. House II: Residential Villa}

This house is located in the residential area of Sultan Qaboos University. It is a two-story building which was constructed in 1986. The ground floor consists of a kitchen, dining room, bath room, store and a living room. The top level contains three bedrooms. The floor area of this house is $50 \mathrm{~m}^{2}$ and ceiling height is $3.5 \mathrm{~m}$.

\section{SAMPLING OF STUDY AREA}

In House I, the air quality parameters were measured in a residential flat, where the levels were recorded in bed room, guest room and kitchen. For House II, two locations (guest room on ground floor room and bed room on first floor), were selected for on-site measurements. The selection of residential houses was made on the basis of various locations of buildings and variability in their ages. The House I is a newly built houses, which were constructed in 2011, while House II was built in 1986. A general review of the selected buildings is described in Table I.

The measurements of indoor air pollutants at all the selected locations were conducted by means of environmental monitoring equipment by GrayWolf Sensing Solutions [3]-[6]. It is a fully integrated system for simultaneous measurements of IAQ parameters, toxic gases and air speed. The WolfPackModular Area Monitor, integrated with IAQ and toxic gases probes, were used in present study to measure $\mathrm{CO}_{2}, \mathrm{CO}$, relative humidity $(\mathrm{RH})$, temperature, $\mathrm{NH}_{3}, \mathrm{NO}, \mathrm{NO}_{2}, \mathrm{SO}_{2}$, $\mathrm{H}_{2} \mathrm{~S}, \mathrm{O}_{3}$, TVOCs, for an averaging period of 15 minutes. The indoor air speed was measured with the help of AS-202A hot anemometer probe. The size distribution and number 
concentration of airborne particles were recorded using a six channel GW-3016 particle counter with channel sizes of 0.3, $0.5,1.0,2.5,5.0$ and $10.0 \mu \mathrm{m}$. WolfSense PC and Advanced Report Generator (ARG) package was used to download the measured data.

TABLE I

OVERVIEW OF HOUSES SELECTED FOR CURRENT STUDY

\begin{tabular}{|l|l|l|}
\hline \multicolumn{1}{|c|}{ Items } & \multicolumn{1}{|c|}{ House I } & \multicolumn{1}{c|}{ House II } \\
\hline Home Type & Residential Flat & Residential Villa \\
\hline No of occupants/Visitors & 4 & 2 \\
\hline Floors except ground floor & 1 & 1 \\
\hline No of kitchens & 1 & 1 \\
\hline Cooking Hours & 2 & 3 \\
\hline $\begin{array}{l}\text { Indoor pollutant sources } \\
\text { except cooking }\end{array}$ & Computer, Carpets & Computer, Carpets \\
\hline Outdoor pollutant sources & $\begin{array}{l}\text { Sanitation company, } \\
\text { Construction work }\end{array}$ & Near main road \\
\hline
\end{tabular}

The evaluation of indoor air quality was carried out by comparing the measured levels of chemical pollutants and factors of thermal comfort with that of international standards or guidelines for averaging periods of 1-hour, 8-hours and 24hours. The comparison was made on the basis of averaged values measured for all periods. The basis of the standards/guidelines values for the residential buildings was based on the effects on human health.

\section{RESULTS AND DISCUSSION}

\section{A. Evaluation of Indoor Air Quality for Averaging Period of 1-Hour}

The assessment of indoor air quality in the residential houses was completed by comparing the prominent levels of air pollutants with that of allowable values defined in various international standards/guidelines. The measured levels of IAQ parameters in the residential houses, for averaging period of 1hour, are represented in Tables II(a) and II(b). It becomes obvious from this table that the measured concentrations of $\mathrm{NO}_{2}, \mathrm{O}_{3}$ and $\mathrm{CO}$, in the indoor environments of the selected houses, were well within limiting values of $0.12 \mathrm{ppm}$ by ASHRAE 62.1 [7], $0.1 \mathrm{ppm}$ by WHO [8] and $25 \mathrm{ppm}$ by WHO [9] respectively.

As illustrated in Table II(a), the averaged measured concentrations of $\mathrm{CO}_{2}$ were $511.4 \mathrm{ppm}, 581.7 \mathrm{ppm}$ and 821.0 $\mathrm{ppm}$ in bed room, guest room and kitchen of House I, respectively. The recorded concentration of $\mathrm{CO}_{2}$ in kitchen was exceeding the standard value of $700 \mathrm{ppm}$ by ASHRAE 62.1 [7] with difference of $17.28 \%$, which is quite acceptable because of sort of activity being carried out in the kitchen. The cooking activity of round about two hours in this residential flat might be a source of elevated levels of $\mathrm{CO}_{2}$ in the kitchen. Alternate explanations behind this level of indoor $\mathrm{CO}_{2}$ might be the deficiency of ventilation and low frequency of window opening in the flat, which was observed during measurement campaign. The higher levels of $\mathrm{CO}_{2}$ in the kitchen were likewise reported in previous studies [10]-[11]. The levels of $\mathrm{CO}_{2}$ recorded in guest and bed rooms of House II were 615.1 ppm and 648.1 ppm respectively which were lower than the allowable value.
The measured concentrations of TVOCs averaged over hourly period were $1250.5 \mu \mathrm{g} / \mathrm{m}^{3}, 1029.0 \mu \mathrm{g} / \mathrm{m}^{3}$, and 758.4 $\mu \mathrm{g} / \mathrm{m}^{3}$ in bedroom, guest room and kitchen of House I respectively. These levels of TVOCs in this residential flat were higher than the suggested threshold of $500 \mu \mathrm{g} / \mathrm{m}^{3}$ [12] with differences of $78.65 \%, 47.0 \%$ and $8.34 \%$ at the above mentioned selected locations respectively. The concentrations of TVOCs in house II are well within the above defined limit.

TABLE II(a)

MEASURED LEVELS OF IAQ PARAMETERS IN RESIDENTIAL HOUSES FOR 1HOUR AVERAGING PERIOD

\begin{tabular}{|c|c|c|c|c|c|c|}
\hline \multirow{2}{*}{\multicolumn{2}{|c|}{ Parameter }} & \multicolumn{3}{|c|}{ House I (Residential Flat) } & \multicolumn{2}{|c|}{$\begin{array}{c}\text { House II } \\
\text { (Residential } \\
\text { Villa) }\end{array}$} \\
\hline & & \multirow{2}{*}{$\begin{array}{l}\begin{array}{l}\text { Bed } \\
\text { Room }\end{array} \\
0.07\end{array}$} & \multirow{2}{*}{$\begin{array}{l}\begin{array}{l}\text { Guest } \\
\text { Room }\end{array} \\
0.09\end{array}$} & \multirow{2}{*}{$\begin{array}{l}\text { Kitchen } \\
0.10\end{array}$} & \multirow{2}{*}{$\begin{array}{l}\begin{array}{l}\text { Guest } \\
\text { Room }\end{array} \\
0.08\end{array}$} & \multirow{2}{*}{$\begin{array}{l}\text { Bed } \\
\text { Room } \\
0.09\end{array}$} \\
\hline $\mathrm{O}_{3}$ & Max. & & & & & \\
\hline & Min. & 0.04 & 0.08 & 0.09 & 0.05 & 0.06 \\
\hline & Ave. & 0.05 & 0.09 & 0.09 & 0.07 & 0.07 \\
\hline \multirow{3}{*}{$\begin{array}{l}\mathrm{NO}_{2} \\
(\mathrm{ppm})\end{array}$} & Max. & 0.06 & 0.05 & 0.17 & 0.10 & 0.10 \\
\hline & Min. & 0.00 & 0.01 & 0.00 & 0.00 & 0.00 \\
\hline & Ave. & 0.01 & 0.04 & 0.02 & 0.00 & 0.00 \\
\hline \multirow{3}{*}{$\begin{array}{l}\mathrm{CO}_{2} \\
(\mathrm{ppm})\end{array}$} & Max. & 768.2 & 1060.4 & 1196.1 & 800.8 & 1016.8 \\
\hline & Min. & 449.6 & 423.6 & 508.2 & 474.6 & 450.0 \\
\hline & Ave. & 511.4 & 581.7 & 821.0 & 615.1 & 648.1 \\
\hline \multirow{3}{*}{$\begin{array}{l}\text { TVOC } \\
\left(\mu \mathrm{g} / \mathrm{m}^{3}\right)\end{array}$} & Max. & 2188.8 & 1945.5 & 1617.3 & 351.8 & 394.0 \\
\hline & Min. & 431.6 & 646.6 & 450.8 & 175.0 & 273.8 \\
\hline & Ave. & 1250.5 & 1029.0 & 758.4 & 248.9 & 331.0 \\
\hline \multirow{3}{*}{$\begin{array}{l}\mathrm{T} \\
\left({ }^{\circ} \mathrm{C}\right)\end{array}$} & Max. & 30.1 & 34.4 & 35.2 & 29.9 & 29.8 \\
\hline & Min. & 23.4 & 31.2 & 32.9 & 22.2 & 23.7 \\
\hline & Ave. & 26.4 & 33.7 & 33.7 & 27.3 & 26.7 \\
\hline \multirow{3}{*}{$\begin{array}{l}\text { RH } \\
(\%)\end{array}$} & Max. & 79.2 & 58.4 & 69.7 & 54.6 & 51.9 \\
\hline & Min. & 38.2 & 38.9 & 38.0 & 40.1 & 30.0 \\
\hline & Ave. & 50.2 & 46.6 & 51.5 & 44.3 & 44.0 \\
\hline \multirow{3}{*}{$\begin{array}{l}\text { Air } \\
\text { Speed } \\
(\mathrm{m} / \mathrm{sec})\end{array}$} & Max. & 0.31 & 0.30 & 0.09 & 0.1 & 0.06 \\
\hline & Min. & 0.00 & 0.00 & 0.01 & 0.03 & 0.04 \\
\hline & Ave. & 0.03 & 0.10 & 0.05 & 0.07 & 0.05 \\
\hline
\end{tabular}

TABLE II(b)

Allowable Standards For 1- Hour Averaging Period

\begin{tabular}{|c|c|c|}
\hline Parameter & Standard/Guideline & Reference \\
\hline $\mathrm{O}_{3}(\mathrm{ppm})$ & $0.12^{\mathrm{b}}$ & ASHRAE 62.1 [7] \\
\hline $\mathrm{NO}_{2}(\mathrm{ppm})$ & $0.1^{\mathrm{b}}$ & WHO [8] \\
\hline $\mathrm{CO}_{2}(\mathrm{ppm})$ & $700^{b}$ & $\begin{array}{l}\text { (continuous exposure) } \\
\text { ASHRAE } 62.1[7]\end{array}$ \\
\hline TVOC $\left(\mu \mathrm{g} / \mathrm{m}^{3}\right)$ & $500^{\mathrm{b}}$ & Brown [12] \\
\hline $\mathrm{T}\left({ }^{\circ} \mathrm{C}\right)$ & $\begin{array}{l}22.5-26.0^{\mathrm{b}} \text { (Summer) } \\
20.0-23.5^{\mathrm{b}} \text { (Winter) }\end{array}$ & ASHRAE-55 [23] \\
\hline RH (\%) & $30-60^{b}$ & ASHRAE-55 [23] \\
\hline Air Speed $(\mathrm{m} / \mathrm{sec})$ & $0.05-0.3^{b}$ & ASHRAE-55 [23] \\
\hline
\end{tabular}

The higher concentrations of TVOCs could give information about the existence of complicated VOC mixtures in the indoor environment of a building. The main sources of TVOCs are building materials, furniture, carpets, solvents, pesticides, aerosol sprays, cleaning agents, and paints [13][15]. The elevated levels of TVOCs observed at all locations of this flat fall in multifactorial exposure range (200-3000 $\mu \mathrm{g} / \mathrm{m}^{3}$ ) defined by Mølhave [16], where the occupants of the dwelling can suffer mucous and skin irritation and general 
discomfort. This discomfort may increase if exposures of other pollutants interact with the exposure of VOCs [17]. Furthermore, the high levels of TVOCs can cause the symptoms of SBS such as headache, fatigue and dizziness, which has been reported in many previous studies [18]-[20]. The higher concentrations of indoor air pollutants especially TVOCs, and the occurrence of SBS is more frequent in newly built dwellings as is the case for this newly built flat, which was constructed in 2011. So the possibility of raised levels of TVOCs in newly dwellings is more as compared with that of old buildings. This finding of current study comes in agreement to previous studies [21]-[22]. The averaged concentrations of TVOCs recorded for this study were also higher in new building as compared with old one. The highest concentration of TVOCs was observed in House I, which was constructed in 2011 as compared to House II which was constructed in 1986. The graphical representation of the highest concentrations of TVOCs measured in these houses along with their ages is shown in Fig. 1.

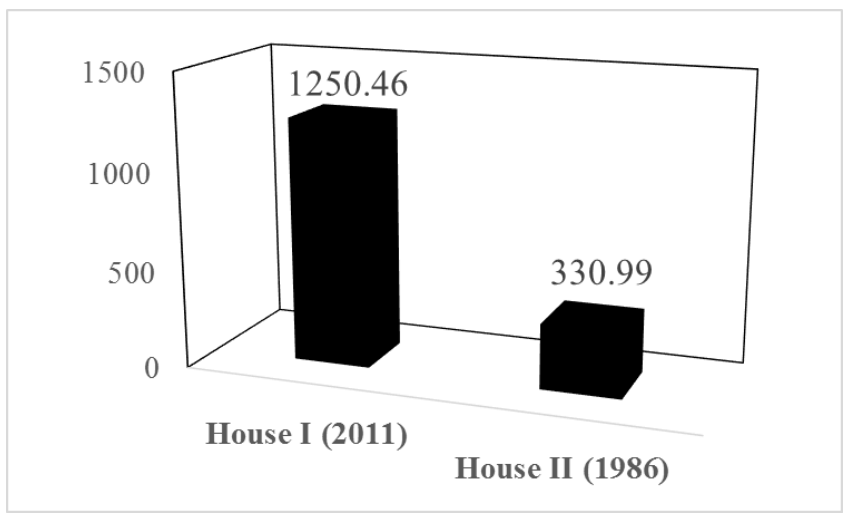

Fig 1. Concentrations of TVOCs in residential buildings according to their ages

It is obvious from Table II(b) that the measured values of temperature in the indoor environment of all the residential buildings are exceeding the range of temperature (22.5-26.0 $\left.{ }^{\circ} \mathrm{C}\right)$ recommended in ASHRAE 55 standard [23]. In House I, the temperature with average values of $26.4{ }^{\circ} \mathrm{C}, 33.7{ }^{\circ} \mathrm{C}$ and $33.7^{\circ} \mathrm{C}$ was logged in bed room, guest room and kitchen with difference of $1.62 \%, 29.69 \%$, and $29.50 \%$ over the allowable range, respectively. The $27.3{ }^{\circ} \mathrm{C}$ and $26.7{ }^{\circ} \mathrm{C}$ temperatures were recorded in the guest room and bed room of House I with differences of $3.92 \%$ and $2.73 \%$ from recommended value respectively. The raised levels of temperatures in all houses can affect the residents. The elevated levels temperatures have been linked to higher prevalence of SBS symptoms among the occupants of the buildings. When the residents of a building are exposed to raised levels of temperature and humidity (26 ${ }^{\circ} \mathrm{C}$ and $60 \%$ ), then more intense SBS symptoms are associated with decreased productivity, including fatigue, headache and difficulty in thinking [24]. So the resident of this flat may complain of thermal discomfort and SBS symptoms due to increase in indoor temperature beyond specified limits. The levels of relative humidity and air speed in all residential houses are within the recommended range of humidity (30-
$60 \%)$ and air speed $(0.05-0.3 \mathrm{~m} / \mathrm{sec})$ by ASHRAE 55 [23].

\section{B. Evaluation of Indoor Air Quality for Averaging Period} of 8-Hour

The measured levels of physical environment and chemical contaminants for averaging period of 8-hours are displayed in Tables III(a) and III(b). It is evident from Table III(b) that the concentrations of $\mathrm{NO}_{2}$ and $\mathrm{CO}$ are very below the standard values of $3 \mathrm{ppm}$ [7] and $10 \mathrm{ppm}$ [9] in the two houses for this averaging period too. The levels of $\mathrm{O}_{3}$ are also within the defined limit of $0.064 \mathrm{ppm}$ [9] at all selected locations of the houses except at the guest room of House I where its value was $0.07 \mathrm{ppm}$ which is higher than the above stated limiting value with a difference of $3.13 \%$. Since $\mathrm{O}_{3}$ is produced from chemical reactions among its precursors in the atmosphere, so its sources are actually the sources of the precursors. The ozone precursors come from fuel combustion and evaporation from off-road engines, construction equipment, agricultural operations, and lawn and garden equipment. Unhealthy ozone levels occur when precursor emissions react in the presence of sunlight, warm temperatures and light winds.

The concentrations of $\mathrm{CO}_{2}(837.8 \mathrm{ppm})$ recorded at kitchen of House I was exceeding the limiting value of $700 \mathrm{ppm}$ with difference of $19.67 \%$. The cooking activity in the kitchen is responsible for this increase. The levels of $\mathrm{CO}_{2}$ at all other selected locations of the houses are lower than the standard value as were in 1-hourly averaging period.

The measured values of TVOCs in the kitchen, guest room and the bedroom of House I were $1203.4 \mu \mathrm{g} / \mathrm{m}^{3}, 1044.3$ $\mu \mathrm{g} / \mathrm{m}^{3}$, and $749.7 \mu \mathrm{g} / \mathrm{m}^{3}$ respectively. The recorded values were again higher than those measured at House II. These levels of TVOCs are again falling in the multifactorial exposure range [16] and can cause the symptoms of SBS and other health hazards in the resident.

The temperatures recorded in the bedroom, guest room and kitchen of House I were $26.2{ }^{\circ} \mathrm{C}, 33.8{ }^{\circ} \mathrm{C}$ and $33.6{ }^{\circ} \mathrm{C}$ respectively, which were again higher than the allowable range of $22.5{ }^{\circ} \mathrm{C}$ to $26{ }^{\circ} \mathrm{C}$ [23]. The differences between the measured and standard value were $0.69 \%, 29.84 \%$ and $29.27 \%$ respectively. In House II, the recorded temperatures in the guest room and the bedroom were $27.5^{\circ} \mathrm{C}$ and $26.7^{\circ} \mathrm{C}$ with $5.81 \%$ and $2.69 \%$ deviation from the above indicated value respectively. Therefore, the temperatures recorded at each location of the two houses were not within the specified limits, as was in hourly averaging period. The raised levels of temperature can increase the occurrence of SBS symptoms among the resident of this house.

The levels of relative humidity and air speed at the two houses were within the acceptable ranges at all the houses. 
TABLE III(a)

Measured LeVels Of Iaq PARAMETERS In Residential Houses For 8HOURS AVERAGING PERIOD

\begin{tabular}{|c|c|c|c|c|c|c|}
\hline \multicolumn{2}{|c|}{ Parameter } & \multicolumn{3}{|c|}{ House I (Residential) } & \multicolumn{2}{|c|}{$\begin{array}{c}\text { House II } \\
\text { (Residential) }\end{array}$} \\
\hline & & $\begin{array}{l}\text { Bed } \\
\text { Room }\end{array}$ & $\begin{array}{l}\text { Guest } \\
\text { Room }\end{array}$ & Kitchen & $\begin{array}{l}\text { Guest } \\
\text { Room }\end{array}$ & $\begin{array}{l}\text { Bed } \\
\text { Room }\end{array}$ \\
\hline \multirow{3}{*}{$\begin{array}{l}\mathrm{O}_{3} \\
(\mathrm{ppm})\end{array}$} & Max. & 0.07 & 0.03 & 0.05 & 0.06 & 0.08 \\
\hline & Min. & 0.04 & 0.01 & 0.02 & 0.06 & 0.02 \\
\hline & Ave. & 0.06 & 0.07 & 0.03 & 0.06 & 0.04 \\
\hline \multirow{3}{*}{$\begin{array}{l}\mathrm{NO}_{2} \\
(\mathrm{ppm})\end{array}$} & Max. & 0.02 & 0.05 & 0.04 & 0.00 & 0.00 \\
\hline & Min. & 0.00 & 0.01 & 0.01 & 0.00 & 0.00 \\
\hline & Ave. & 0.01 & 0.04 & 0.02 & 0.00 & 0.00 \\
\hline \multirow{3}{*}{$\begin{array}{l}\mathrm{CO}_{2} \\
\text { (ppm) }\end{array}$} & Max. & 568.5 & 700.2 & 1105.5 & 676.6 & 841.0 \\
\hline & Min. & 456.2 & 502.5 & 654.6 & 567.7 & 519.4 \\
\hline & Ave. & 508.2 & 578.6 & 837.8 & 62.6 & 657.7 \\
\hline \multirow{3}{*}{$\begin{array}{l}\text { TVOC } \\
\left(\mu \mathrm{g} / \mathrm{m}^{3}\right)\end{array}$} & Max. & 1493.3 & 1355.8 & 900.2 & 266.6 & 372.0 \\
\hline & Min. & 913.4 & 780.5 & 552.3 & 234.8 & 296.8 \\
\hline & Ave. & 1203.4 & 1044.3 & 749.7 & 250.0 & 332.6 \\
\hline \multirow{3}{*}{$\begin{array}{l}\mathrm{T} \\
\left({ }^{\circ} \mathrm{C}\right)\end{array}$} & Max. & 27.8 & 34.1 & 34.2 & 27.9 & 27.6 \\
\hline & Min. & 24.2 & 33.6 & 33.3 & 27.0 & 25.3 \\
\hline & Ave. & 26.2 & 33.8 & 33.6 & 27.5 & 26.7 \\
\hline \multirow[t]{3}{*}{$\mathrm{RH}(\%)$} & Max. & 54.3 & 48.3 & 61.3 & 44.7 & 5043 \\
\hline & Min. & 41.7 & 44.5 & 45.8 & 44.1 & 36.0 \\
\hline & Ave. & 49.1 & 46.6 & 51.7 & 44.4 & 44.6 \\
\hline \multirow{3}{*}{$\begin{array}{l}\text { Air } \\
\text { Speed } \\
(\mathrm{m} / \mathrm{sec})\end{array}$} & Max. & 0.31 & 0.10 & 0.09 & 0.10 & 0.03 \\
\hline & Min. & 0.00 & 0.00 & 0.01 & 0.02 & 0.01 \\
\hline & Ave. & 0.09 & 0.03 & 0.05 & 0.05 & 0.02 \\
\hline
\end{tabular}

TABLE III(b)

ALLOWABLE STANDARDS FOR 8-HOURS AVERAGING PERIOD

\begin{tabular}{|l|l|l|}
\hline Parameter & \multicolumn{1}{|c|}{ Standard/Guideline } & Reference \\
\hline $\begin{array}{l}\mathrm{O}_{3} \\
(\mathrm{ppm})\end{array}$ & $0.064^{\mathrm{b}}$ & WHO [9] \\
\hline $\begin{array}{l}\mathrm{NO}_{2} \\
(\mathrm{ppm})\end{array}$ & $3^{\mathrm{b}}$ & ASHRAE 62.1 [7] \\
\hline $\begin{array}{l}\mathrm{CO} \\
(\mathrm{ppm})\end{array}$ & $700^{\mathrm{b}}$ (continuous exposure) & ASHRAE 62.1 [7] \\
\hline $\begin{array}{l}\mathrm{TVOC} \\
\left(\mu \mathrm{g} / \mathrm{m}^{3}\right)\end{array}$ & $\begin{array}{l}<200^{\mathrm{b}} \text { (comfort range) } \\
200-3000^{\mathrm{b}} \text { (multifactorial } \\
\text { exposure range) }\end{array}$ & Mølhave [16] \\
\hline $\begin{array}{l}\mathrm{T} \\
\left({ }^{\circ} \mathrm{C}\right)\end{array}$ & $\begin{array}{l}22.5-26.0^{\mathrm{b}}(\text { Summer }) \\
20.0-23.5^{\mathrm{b}} \text { (Winter) }\end{array}$ & ASHRAE-55 [23] \\
\hline $\mathrm{RH}(\%)$ & $30-60^{\mathrm{b}}$ & ASHRAE-55 [23] \\
\hline $\begin{array}{l}\text { Air Speed } \\
(\mathrm{m} / \mathrm{sec})\end{array}$ & $0.05-0.3^{\mathrm{b}}$ & ASHRAE-55 [23] \\
\hline
\end{tabular}

\section{Evaluation of Indoor Air Quality for Averaging Period of 24-hours}

Tables IV(a) and IV(b) summarizes the measured parameters of IAQ on the basis of daily average. It is obvious from Table IV(b) that the levels of $\mathrm{O}_{3}, \mathrm{NO}_{2}, \mathrm{CO}$, relative humidity and air speed are in accordance with the threshold values, stated in the table. The concentration of $\mathrm{CO}_{2}$ measured in the kitchen of House I was $17.29 \%$ upper from the limiting value of $700 \mathrm{ppm}$. The other locations of all the houses were presenting the acceptable situation regarding to $\mathrm{CO}_{2}$ on daily averaged basis.

The concentrations of TVOCs recorded at all the selected locations of House I, and House II were again following the multifactorial exposure range $\left(200-3000 \mu \mathrm{g} / \mathrm{m}^{3}\right)$ specified on daily average basis [16].

The temperatures recorded at all locations of selected houses were exceeding the defined range of $20.5^{\circ} \mathrm{C}$ to $26.0^{\circ} \mathrm{C}$ [23] for daily averaging period too. In House $\mathrm{I}$, the temperatures recorded at bedroom, guest room and kitchen were $1.62 \%, 29.69 \%$ and $29.50 \%$ upper than the limiting range while $4.85 \%$ and $2.77 \%$ difference was noted in the guest room and bedroom of House II. Here again the increased temperature in House I on daily average basis, may cause adverse health effects.

TABLE IV(a)

Measured LeVels Of IaQ PARAMETERs In Residential Houses For 24HOURS AVERAGING PERIOD

\begin{tabular}{|l|l|l|l|l|l|}
\hline \multirow{2}{*}{ Parameter } & \multicolumn{3}{|c|}{ House I (Residential) } & \multicolumn{2}{c|}{$\begin{array}{c}\text { House II } \\
\text { (Residential) }\end{array}$} \\
\cline { 2 - 6 } & $\begin{array}{l}\text { Bed } \\
\text { Room }\end{array}$ & $\begin{array}{l}\text { Guest } \\
\text { Room }\end{array}$ & Kitchen & $\begin{array}{l}\text { Guest } \\
\text { Room }\end{array}$ & $\begin{array}{l}\text { Bed } \\
\text { Room }\end{array}$ \\
\hline $\begin{array}{l}\mathrm{O}_{3} \\
(\mathrm{ppm})\end{array}$ & 0.05 & 0.03 & 0.04 & 0.04 & 0.05 \\
\hline $\begin{array}{l}\mathrm{NO}_{2} \\
(\mathrm{ppm})\end{array}$ & 0.01 & 0.04 & 0.02 & 0.00 & 0.00 \\
\hline $\begin{array}{l}\mathrm{CO}_{2} \\
(\mathrm{ppm})\end{array}$ & 511.4 & 581.7 & 821.0 & 614.8 & 647.1 \\
\hline $\begin{array}{l}\mathrm{TVOC} \\
\left(\mu \mathrm{g} / \mathrm{m}^{3}\right)\end{array}$ & 1250.4 & 1029.4 & 759.1 & 248.9 & 330.7 \\
\hline $\begin{array}{l}\mathrm{T} \\
\left({ }^{\circ} \mathrm{C}\right)\end{array}$ & 26.4 & 33.7 & 33.7 & 27.3 & 26.7 \\
\hline $\begin{array}{l}\mathrm{RH} \\
(\%)\end{array}$ & 50.2 & 46.6 & 51.8 & 44.3 & 43.9 \\
\hline $\begin{array}{l}\text { Air Speed } \\
(\mathrm{m} / \mathrm{sec})\end{array}$ & 0.03 & 0.01 & 0.01 & 0.04 & 0.01 \\
\hline
\end{tabular}

TABLE IV(b)

Allowable Standards For 24-Hours AVERAGing Period

\begin{tabular}{|l|l|l|}
\hline Parameter & Standard/Guideline & Reference \\
\hline $\begin{array}{l}\mathrm{O}_{3} \\
(\mathrm{ppm})\end{array}$ & - & - \\
\hline $\begin{array}{l}\mathrm{NO}_{2} \\
(\mathrm{ppm})\end{array}$ & $0.21^{\mathrm{b}}$ & WHO [8] \\
\hline $\begin{array}{l}\mathrm{CO}_{2} \\
(\mathrm{ppm})\end{array}$ & $700^{\mathrm{b}}$ (continuous exposure) & ASHRAE 62.1 [7] \\
\hline $\begin{array}{l}\mathrm{TVOC} \\
\left(\mu \mathrm{g} / \mathrm{m}^{3}\right)\end{array}$ & $\begin{array}{l}<200^{\mathrm{b}} \text { (comfort range) } \\
200-3000^{\mathrm{b}} \text { (multifactorial } \\
\text { exposure range) }\end{array}$ & Mølhave [16] \\
\hline $\begin{array}{l}\mathrm{T} \\
\left({ }^{\circ} \mathrm{C}\right)\end{array}$ & $\begin{array}{l}22.5-26.0^{\mathrm{b}} \text { (Summer) } \\
20.0-23.5^{\mathrm{b}} \text { (Winter) }\end{array}$ & ASHRAE-55 [23] \\
\hline $\begin{array}{l}\mathrm{RH} \\
(\%)\end{array}$ & $30-60^{\mathrm{b}}$ & ASHRAE-55 [23] \\
\hline $\begin{array}{l}\text { Air Speed } \\
(\mathrm{m} / \mathrm{sec})\end{array}$ & $0.05-0.3^{\mathrm{b}}$ & ASHRAE-55 [23] \\
\hline
\end{tabular}

The measured levels IAQ parameters especially the concentrations of TVOCs for daily averaging period were again higher for newly built flat (House I) as compared with House II under study, which is a clear indication of presence of indoor sources of TVOCs in this residential flat.

In the light of above discussed results, it is obvious that the quality of air in residential flat (House I) was not acceptable due to higher levels of CO2, TVOCs and temperature in the indoor environment, for short term exposure as well as for long term exposures. The raised levels of these pollutants 
could cause adverse health effects on the residents of the house including SBS.

\section{V.CONCLUSION}

The levels of IAQ parameters were recorded at various locations of the two residential houses. The measured levels of IAQ parameters were compared with the permitted values defined by international standards/guidelines. The results demonstrated that the quality of air in newly built flat (House I) was not acceptable because of the higher levels of $\mathrm{CO}_{2}$, TVOCs and temperature in the indoor environment, for short term exposure and also for long term exposure. The raised levels of these pollutants could bring about adverse health effects on the occupants of the house including SBS. The status of indoor air in House II was more satisfactory as compared with House I. The elevated levels of TVOCs and temperatures were concerning focuses for these houses as well.

\section{REFERENCES}

[1] A. R. Pickett, and M. L. Bell, "Assessment of indoor air pollution in homes with infants," Int. J. Environ. Res., vol. 8, pp. 4502-4520, 2011. https://doi.org/10.3390/ijerph8124502

[2] J. Jansz, "Introduction to sick building syndrome," in Sick Building Syndrome in public building and workplace, S. A. Abdul-Wahab, Ed. London, New York: Springer Heidelberg Dordrecht, 2011, pp 1-24.

[3] A. Hariri, A. M. Leman, M. Z. M. Yusof, N. A. Paiman, and N. M. Noor, "Preliminary measurement of welding fumes in automotive plants," IJESD. vol. 3(2), pp. 146-151, 2012. https://doi.org/10.7763/IJESD.2012.V3.205

[4] H. Lee, J. L. Lee, S. Y. Park, Y. W. Kim, and Y. Lee, "The improvement of ventilation behaviors in kitchens of residential buildings," Indoor Built Environ., vol.2011;000:1-14.

[5] F. Muhamad-darus, A. Zain-ahmed, and M. Talib, "Preliminary assessment of indoor air quality in terrace houses," Health and the Environmental Journal, vol. 2(2), pp. 8-14, 2011.

[6] P. N. Pegas, M. G. Evtyugina, C. A. Alves, T. Nunes, M. Cerqueira, Franchi, C. A. Pio, S. M. Almeida, and M. C. Freitas, "Outdoor/indoor air quality in primary schools in Lisbon: a preliminary study,". Quim Nova., vol. 1145-1149, 2010.

[7] ASHRAE Standard 62.1, "Ventilation for acceptable indoor air quality," American Society of Heating, Refrigerating and Air-Conditioning Engineers, 1791 Tullie Circle NE, Atlanta, GA 30329, 2007.

[8] WHO (World Health Organization), "WHO guidelines for indoor air quality: selected pollutants," World Health Organization Regional Office for Europe, 2010.

[9] WHO (World Health Organization), "Air quality guidelines for Europe," $2^{\text {nd }}$ edition, World Health Organization regional publications, European series No. 91, 2000.

[10] S. Palanivelraja, and K. I. Manirathinem, "A comparative study on indoor air quality in a low cost and a green design house," Afr. J. Environ. Sci. Technol., vol. 3(5), pp. 120-130, 2009.

[11] S. C. Lee, W. M. Li, and C. H. Ao, "Investigation of indoor air quality at residential homes in Hong Kong-case study," Atmospheric Environment, vol. 36, pp. 225-237, 2002. https://doi.org/10.1016/S1352-2310(01)00435-6

[12] S. K. Brown, High Quality Indoor Environments for Sustainable Office Buildings. Australian CRC for Construction Innovation, 2008.

[13] J. Kowalska, and T. Gierczak, "Qualitative and quantitative analyses of the halogenated volatile organic compounds emitted from the office equipment items," Indoor Built Environ, vol. 22(6), pp. 920-931, 2013. https://doi.org/10.1177/1420326X12458299

[14] P. N. Pegas, M. G. Evtyugina, C. A. Alves, T. Nunes, M. Cerqueira, C. A. Franchi, Pio, S. M. Almeida, and M. C. Freitas, "Outdoor/indoor air quality in primary schools in Lisbon: a preliminary study," Quim Nova., vol. 33(5), pp. 1145-1149, 2010.

https://doi.org/10.1590/S0100-40422010000500027
[15] A. Bello, M. M. Quinn, M. J. Perry, and D. K. Milton, "Quantitative assessment of airborne exposures generated during common cleaning tasks: a pilot study," Environ Health., vol. 9(1), pp. 76-84, 2010. https://doi.org/10.1186/1476-069X-9-76

[16] L. Mølhave, "Volatile organic compounds, indoor air quality, and health," Indoor Air., vol. 1, pp. 357-376, 1991. https://doi.org/10.1111/j.1600-0668.1991.00001.x

[17] J. L. Niu, and J. Burnett, "Setting up the criteria and credit-awarding scheme for building interior material selection to achieve better indoor air quality," Environ Intl., vol. 26(7-8), pp. 573-580, 2001. https://doi.org/10.1016/S0160-4120(01)00043-5

[18] Z. Sulaiman, and M. Mohamed, "Indoor air quality and sick building syndrome study at two selected libraries in Johor Bahru, Malaysia," Environment Asia, vol. 491), pp. 67-74, 2011.

[19] I. Syazwan Aizat, J. Juliana, O. Norhafizalina, Z. A. Azman, and J. Kamaruzaman, "Indoor air quality and sick building syndrome in Malaysian buildings," Glob J Health Sci., vol. 1(2), pp. 126-136, 2009.

[20] B. L. Wang, T. Takigawa, Y. Yamasaki, N. Sakano, D. H. Wang, and K. Ogino, "Symptom definitions for SBS (sick building syndrome) in residential dwellings," Int J Hyg Environ Health., vol. 211(1-2), pp. 114-120, 2008. https://doi.org/10.1016/j.ijheh.2007.03.004

[21] Y. Saijo, Y. Nakagi, T. Ito, Y. Sugioka, H. Endo, and T. Yoshida, "Relation of dampness to sick building syndrome in Japanese public apartment houses," Environ Health Prev Med., vol. 14(1), pp. 26-35. 2009. https://doi.org/10.1007/s12199-008-0052-y

[22] W. Yang, J. Sohn, J. Kim, B. Son, and J. Park, "Indoor air quality investigation according to age of the school buildings in Korea," $J$. Environ. Manage., vol. 90(1), pp. 348-354, 2009. https://doi.org/10.1016/j.jenvman.2007.10.003

[23] ASHRAE Standard 55. Thermal environmental conditions for human occupancy. 2010, American Society of Heating, Refrigerating and AirConditioning Engineers, 1791 Tullie Circle NE, Atlanta, GA 30329, 2010.

[24] L. Fang, D. P. Wyon, G. Clausen, and P. O. Fanger. "Sick building syndrome symptoms and performance in a field laboratory study at different levels of temperature and humidity," Indoor Air, vol. 3, pp. 466-461. 